\title{
Comparative Analysis of Dance Education and Teaching between Colleges and Universities in China and South Korea - Using Zhaoqing University in China and Gyeongsang National University in South Korea as Examples
}

\author{
Xun Lan \\ Zhaoqing University, Zhaoqing 526060, Guangdong, China \\ DOI: $10.32629 /$ jher.v2i6.585
}

\begin{abstract}
With the increase in demand for art education and art culture, dance education at universities is being paid more and more attention. At present, in addition to colleges and universities majoring in dance, many comprehensive colleges and universities have quickly incorporated dance majors into their curricula, which has promoted the development of dance as a discipline, but also produced many problems. Zhaoqing University and Gyeongsang National University are two local comprehensive universities offering dance majors in China and South Korea. This paper compares the dance education and teaching levels of the two universities from the perspective of professional development history, discipline construction and education and teaching courses. It also analyzes existing problems, and proposes that we should continuously improve the training programs for dance students and encourage professional development of dance teachers, while encouraging the construction of hardware facilities and paying attention to the educational role of folk dance, so as to further improve the dance education and teaching quality of local comprehensive colleges and universities.
\end{abstract}

Keywords: comparison between China and South Korea, art education, education comparison, universities in China and Korea, Chinese dance, Korean dance

\section{Introduction}

The dance arts of China and South Korea play an important role in the dance culture of East Asia. The difference of dance between the two countries is not only affected by their traditional culture, but also by the differences between the two countries' dance education systems. Scientifically based education and teaching settings are important to allow theoretical guidance of dance students during training. Based on the author's undergraduate, post-graduate and work experience, this study investigates dance education in Korean and Chinese universities and puts forward problems observed in these institutions, and explores ways to improve the effectiveness of education and teaching. This paper will analyze the current situation of undergraduate education and teaching in the dance departments of ZUC and GNUK, analyze differences between them, find existing problems, and further explore ways to improve the teaching effectiveness of dance education, so as to provide supporting materials for further improving the teaching quality of dance education. It is hoped that through the comparative analysis of this paper, the problems and suggestions put forward in this paper can be used in practice to improve and enrich the dance teaching system of colleges and universities in the two countries.

\section{Comparison of dance education and teaching systems between colleges and universities in China and South Korea}

\subsection{Introduction to dance majors in two universities; one in China; one in South Korea}

ZUC is a public full-time comprehensive undergraduate university, located in Zhaoqing City, Guangdong Province. The College of Music is a secondary college of ZUC. In 2012, the College of Music established the Dance Department. It is currently recruiting undergraduates.

GNUK is a national full-time comprehensive university, located in Jinzhou City, Gyeongsang South Road, Korea. The College of Humanities is one of the 14 colleges at the university, and the Department of Folk Dance is one of the 10 departments in this college. The Department of Folk Dance was established in 1997. It currently recruits undergraduate, master's and doctoral students and offers three undergraduate majors, "Comparative Folk Dance", "Korean Folk Dance" and "Modern Dance". 


\subsection{Comparison of educational facilities}

In terms of training facilities, the Dance Department of ZUC has 6 professional dance classrooms equipped with professional dance floors, multimedia equipment, dressing room and other equipment, with a total area of more than 1,040 square meters. In recent years, the Dance Department has improved the quality and quantity of teaching staff by recruiting several young teachers from famous universities at home and abroad. There are 11 full-time teachers, including 1 professor, 1 associate professor, 6 lecturers and 3 teaching assistants. The age structure, academic structure and organizational structure of the teaching staff are all reasonable, and the quality of the professional team of dance teachers is improving.

By comparison, GNUK has four dance training rooms equipped with professional floors, ballet bars, multimedia equipment, dressing rooms and other equipment. It has excellent organizational structure and teaching quality. It has many of Korea's most recognized and influential teachers. There are 4 professors in the department, and more than 20 part-time teachers with strong ability, solid professional knowledge. For example the staff includes several Korean Living National Treasures who hold Important Intangible Cultural Properties of Korea. These include: Jin Long, holder of art No. 39, Cheoyongmu, Yan Yuzi, holder of art No. 21, Seungjeonmu; and Jin Zhengnv, the teaching assistant of No. 97, Salpurichum.

Both departments occupy a middle to upper position when compared to the similar departments at other universities in the respective countries. Both have good facilities and faculty, can meet daily teaching requirements, and help to cultivate students with strong dance performance ability and high professional quality. When comparing the development stages of the two universities, the Dance Department of ZUC is in the "vigorous growth" stage. The facilities are stage of the art, and the teaching team is young and energetic, which brings new ideas and new paths to dance education and teaching. However, the Dance Department of GNUK is already well established, and the hardware facilities are more comprehensive. On the other hand, the strength of dance teachers at GNUK is stronger than that of ZUC, and dance education and teaching is also relatively well developed.

\subsection{Comparison of theoretical and practical courses}

Table 1. Comparison of theoretical and practical courses

\begin{tabular}{|c|c|c|}
\hline \multirow{2}{*}{ Type of courses } & \multicolumn{2}{|c|}{ Course content } \\
\hline & Zhaoqing University in China & Gyeongsang National University in South Korea \\
\hline $\begin{array}{l}\text { Professional } \\
\text { theory courses }\end{array}$ & $\begin{array}{l}\text { Chinese dance history, western dance history, dance } \\
\text { psychology, dance pedagogy, dance aesthetics, dance } \\
\text { anatomy, introduction to dance, fundamentals of music } \\
\text { theory and solfeggio, etc. }\end{array}$ & $\begin{array}{l}\text { Korean dance history, world dance history, introduction } \\
\text { to dance, dance education theory, dance education } \\
\text { development, dance physiological decomposition, } \\
\text { Chinese culture and art, introduction to Korean music, } \\
\text { etc. }\end{array}$ \\
\hline $\begin{array}{c}\text { Professional } \\
\text { practice courses }\end{array}$ & $\begin{array}{l}\text { Fundamentals of dancing, Chinese classical dance basic } \\
\text { training, modern dance basic training, Chinese folk } \\
\text { dance, Chinese classical dance body rhythm, repertoire } \\
\text { rehearsal, dance creation repertoire rehearsal, stage } \\
\text { performance art, artistic style piano foundation, vocal } \\
\text { music foundation, dance graduation special session, } \\
\text { graduation practice, etc. }\end{array}$ & $\begin{array}{l}\text { Basic Korean dance, modern dance, Asian folk dance, } \\
\text { dance creation practice, dance special lecture, Korean } \\
\text { dance field investigation, Asian national dance practice, } \\
\text { folk dance percussion instrument, singing practice, dance } \\
\text { creation practice, graduation work performance, etc. }\end{array}$ \\
\hline
\end{tabular}

ZUC and GNUK have similar dance curricula. They both offer dance theory courses, practical dance courses and auxiliary professional dance courses. They both also pay attention to the combination of students' practice and theory and cultivate high-quality and all-round applied talents with comprehensive theoretical knowledge, practical ability and teaching ability.

In terms of dance theory courses, the two universities attach importance to the theoretical construction of the dance major. But relatively speaking, ZUC has richer theoretical courses and is more inclined to the cultivation of dance teachers. In terms of practical courses at ZUC, graduation practice is an important link in the teaching plan. Students about to graduate are assigned to primary and secondary schools in the province to exercise their knowledge application ability and social adaptability. GNUK has three undergraduate majors, "Comparative Folk Dance", "Korean Folk Dance" and "Modern Dance". It offers courses in three fields: Korean traditional dance, foreign dance and modern dance. All the three fields are compulsory courses, but courses in the other two fields will be allocated proportionally according to the students' major. In the special dance course, holders of Korean National Intangible Cultural Heritage Properties in dance are invited to teach students, which is conducive to the protection, inheritance, and dissemination of cultural heritage. Both universities attach great importance to the construction of professional dance practice courses, but GNUK has more courses and more comprehensive training of professional practice ability. 


\section{Problems in dance education and teaching in colleges and universities of the two countries}

\subsection{Personnel training and teaching staff}

The professional dance talent training program of GNUK has set up three professional directions according to the dance field, which can cultivate diversified talent types, such as performing talents, creative talents, academic talents or pedagogical talents, but the training objectives are not clear, resulting in unclear teaching methods of teachers and students' loss of motivation and objectives in the learning process. The talent training program is out of touch with students' development and social needs, resulting in deviations in talent training programs and methods. At the level of teaching staff, due to the particularity of dance major, compared with teachers in other majors, some dance teachers have rich teaching experience but low educational background, which is more obvious in Chinese universities. The educational background of teachers engaged in dance education is mainly of master's degree. The main reasons are that there are few doctoral programs specializing in dance; dance majors focus on practical teaching, and some teachers think it is not necessary to continue studying. However, every field and every business needs to develop of high-level talents. The lack of highly educated dance teachers is not conducive to the deepening of dance theory, the development of dance culture, the dissemination of dance as art or the expansion of the influence of dance.

\subsection{Carrier and hardware facilities of education and teaching}

The theoretical and practical dance courses at the two universities are mainly based on conventional theory and dance practice. However, both the universities are local universities with strong folk cultural heritage. With the improvement of the awareness of the two countries on the protection of Intangible Cultural Heritage, as an important education base for talent training, how to use the advantages of colleges and universities to carry forward the Intangible Cultural Heritage Dance of various countries is a problem that schools of the two countries need to think about. From the perspective of hardware facilities, at this stage, colleges and universities in the two countries pay more and more attention to the development of art majors, and the supporting facilities are constantly being improved, which basically meets the requirements of talent training. Compared with the direct promotion of science technology and traditional humanities to social economy, dance art is still a relatively marginal field. In this case, facilities include teaching environment, learning environment and so on. At this stage, comparing the disciplines of dance with science technology, the state and universities pay less attention to dance. There are not many dance teaching venues in the Dance Department of GNUK, and the students find the space uncomfortable. Although ZUC has six professional dance classrooms equipped with multimedia equipment and other equipment, they have limited service life and some are even damaged, and cannot be repaired in time, resulting in the failure to maximize teaching effectiveness and affecting student enthusiasm negatively.

\section{Exploring the way to improve the teaching effect of dance education in colleges and universities}

\subsection{Improving dance talent training programs}

When formulating dance talent training plans, it is necessary to clarify the training direction and establish the characteristics of the school. Have in-depth exchanges with enterprises and schools, understand the actual needs of employers, and cultivate dance talent in line with social needs. Regularly communicate with students to understand their feedback on professional training, and adjust the scheme according to the actual situation. On the basis of continuing to pay attention to and consolidate students' dance theoretical knowledge, we should improve practical teaching and improve dance skills of dance majors. In addition, in order to further improve the training effectiveness of dance talent, we can strengthen the discipline exchange between colleges and universities, learn from each other, learn successful training experience, and establish a perfect training scheme of dance talent.

\subsection{Improving the professional level of dance teachers}

"Teachers are those who can propagate the doctrine, impart professional knowledge, and resolve doubts". Dance teachers are no exception. They are the builders and disseminators of human dance culture. The quality of dance teachers directly affects the quality of teaching and determines the level and development direction of dance education. Therefore, dance teachers need to constantly improve their own quality in order to gain something. In terms of the construction of teachers' team, dance teachers should have a reasonable professional title structure, education structure and age structure to ensure the professional quality of teachers, maintain vitality and keep forging ahead. Subdivide dance teachers' professional 
fields and reasonably allocate teaching courses, so as to make teachers' professional teaching ability play a more effective role. Continuously improve the academic structure, set up incentive policies to encourage master professional dance teachers to study for dance doctoral students, and improve the professional level of dance teachers. Strengthen the training of dance teachers, regularly hold or participate in exchange meetings for dance teachers in colleges and universities, special training lectures, research and scientific research promotion lectures in colleges and universities at home and abroad, so as to consolidate professional knowledge and broaden professional ideas.

\subsection{Strengthening the construction of hardware facilities}

The construction of colleges and universities is mainly to train talents for the country, enable students to obtain basic social survival skills through learning in colleges and universities, and make positive preparations for students to go out of colleges and universities and enter the society in the future. From this point of view, the existence of colleges and universities should be student-centered. In this regard, in addition to the level of teachers and management level, teaching hardware facilities have also played a very positive role. In most comprehensive universities, dance major is not the main development goal. For dance majors, a professional teaching place equipped with multimedia equipment, glue etc. can not only improve students' professional identity, but also improve teaching quality. Therefore, in order to further improve the effective of dance education, no matter what type of colleges and universities, as long as they set up dance majors, they should first reasonably allocate resources, strengthen the construction of hardware facilities, set up enough dance classrooms and support modern professional equipment.

\subsection{Highlighting the carrier function of regional dance education}

Local undergraduate colleges and universities have their own advantages and limitations. Local colleges and universities must consider many factors in cultivating dance professionals. They should adjust measures to local conditions and teach students according to their aptitude, which meets the needs of local society and has regional characteristics. The dance education of ZUC and GNUK should give full play to the advantages of dance disciplines in local colleges and universities and undertake the great responsibility of protecting and inheriting the cultural heritage of national folk dance. The two universities can integrate the local intangible cultural heritage dance resources according to the discipline characteristics and bring the "Intangible Cultural Heritage" dance courses into the teaching system. The combination of local dance and dance education not only promotes the teaching effect of dance education to a higher level, but also maximizes the role of dance discipline in colleges and universities.

\section{Acknowledgments}

This paper is the research results of the 2017 key education research project of Zhaoqing Education Development Institute (project approval No.: ZQJYY2017041).

\section{References}

[1] Wu XZ, Lu XZ. Research on the improvement scheme of university dance education. In: Korean Dance Research, 37 series. Korean Dance Research Society. 2012: 175-202.

[2] Li C. In comparison to discuss the college dance education of China. Journal of Chengdu Normal University. 2013; (4): 26-28.

[3] Li C. On the important role of dance education in school talent training (in Chinese). Art and Literature for the Masses (Academic Edition). 2012; (18): 237.

[4] Zhao Y. Reflection on problems in the current situation of Chinese dance education - High development of technology and low wandering of cultural foundation (in Chinese). Ethnic Art Studies. 2011; (4): 48-51.

[5] Yu M. A study on present situation and analysis of Chinese professional education for dance [Master's Thesis]. Jinan: Shandong Normal University. 2011: 46.

[6] Liu G. My opinion on Korean traditional dance teaching methods (in Chinese). Music Life. 2012; (12): 59-60. 